\title{
ПСИХОЛОГІЧНИЙ СКЛАДНИК ПРОФЕСІЙНОЇ ДІЯЛЬНОСТІ ФАХІВЦІВ АГРОНОМІЧНОГО ПРОФІЛЮ
}

Полозенко О.В. Психологічний складник професійної діяльності фахівців агрономічного профілю.

У статті проаналізовано професійні обов'язки, виробничі функції, типові задачі професійної діяльності фахівців агрономічного профілю, потенціал фаху щодо працевлаштування й застосування на практиці набутих професійних знань, умінь і навичок. Виокремлено психологічний складник професійної діяльності фахівців агрономічного профілю.

Ключові слова: аграрна галузь, агроном, психологічна підготовка.

Полозенко O. В. Психологическая составляющая профессиональной деятельности специалистов агрономического профиля.

В статье проанализированы профессиональные обязанности, производственные функции, типичные задачи профессиональной деятельности специалистов агрономического профиля, потенциал профессии относительно трудоустройства и применения на практике приобретенных профессиональных знаний, умений и навыков. Выделена психологическая составляющая профессиональной деятельности специалистов агрономического профиля.

Ключевые слова: аграрная отрасль, агроном, психологическая подготовка.

Polozenko O. V. Psychological component of professional activity of specialists of agronomical type.

Professional duties, production functions, typical tasks of professional activity of specialists of agronomical type, potential of profession are analysed in the article, in relation to employment and application of the in practice purchased professional knowledges, abilities and skills. The psychological component of professional activity of specialists of agronomical type is selected.

Key words: agrarian industry, agronomist, psychological training.

Україна - аграрно-промислова держава, одна 3 найбагатших держав світу на землю сільськогосподарського призначення, тому становлення економіки України значною мірою залежить від успішного розвитку ії аграрного сектору. Для України сільське господарство має особливо велике значення, оскільки $\epsilon$ однією 3 найбільших галузей народного господарства. Про місце галузі в економіці країни свідчить той факт, що на початок XXI століття сільське населення України становило $32 \%$ від загальної кількості населення. У сільському господарстві залучено $23 \%$ від усіх працюючих. Важливо зазначити, що понад $80 \%$ фонду споживання формується за рахунок продукції сільського господарства.

Прискорення відродження села потребує відповідного кадрового забезпечення шляхом зміщення акцентів на людський чинник. В умовах економічних реформ в Україні професійна діяльність фахівців аграрної галузі набуває особливої соціальної значущості й істотно ускладнюється, актуалізуючи важливість психологічних ресурсів особистості. Збільшення навантаження, інтенсифікація діяльності, ненормований графік роботи, виконання професійних обов'язків у несприятливих погодних умовах і складних виробничих ситуація - ці та інші

Педагогіка вищої та середної школи. - 2014. - Вип. 40. 
чинники посилюють вимоги до психологічної готовності фахівців аграрної галузі до професійної діяльності.

Тенденція особистісного пріоритету в освітньому процесі передбачає орієнтацію студентів у галузі знань про себе, про власні можливості, особистісний потенціал, шляхи його реалізації та розвитку у процесі професійної підготовки. Зважаючи на викладене вище, забезпечення аграрної галузі фахівцями та їхня психологічна підготовка до професійної діяльності є однією з актуальних проблем сьогодення.

Аналіз останніх досліджень і публікацій свідчить, що різноманітні проблеми підготовки кадрів для аграрної галузі останнім часом інтенсивно досліджуються вітчизняними науковцями, зокрема: формування навчально-пізнавальної активності студентів в аграрних ВНЗ (П. Лузан), ступеневе навчання майбутніх інженерівмеханіків сільськогосподарського виробництва (В. Манько), підготовка майбутніх фахівців аграрної галузі до управлінської діяльності (В. Свистун), навчання професійного спілкування студентів аграрного ВНЗ (Л. Барановська), професійне навчання молодшого спеціаліста сільськогосподарського профілю (В. Лозовецька), ступенева підготовка майбутніх екологів (Н. Рідей), формування культури професійного спілкування студентів аграрного ВНЗ (С. Амеліна), практична підготовка студентів техніко-технологічних спеціальностей в аграрних ВНЗ (М. Хоменко), професійне становлення студенток в аграрних ВНЗ (С. Виговська), навчання дисциплін гуманітарного циклу студентів агротехнічного інституту (Н. Островська), підготовка студентів аграрних спеціальностей до професійного спілкування в іншомовному середовищі (Ю. Ніколаєнко), підготовка майбутніх економістів-аграрників до професійної інформаційної діяльності (Р. Корнєв), формування інформаційно-комунікаційної компетентності майбутніх фахівців аграрних спеціальностей (П. Пахотіна), культурологічна підготовка майбутніх фахівців агротехнологічного спрямування (Т. Мельничук), професійна підготовка інженерів-аграрників в системі вищої освіти США (О. Вощевська), формування працеохоронних умінь і навичок студентів аграрних ВНЗ (В. Жданова), формування управлінської компетентності майбутніх магістрів лісового господарства (Л. Макодзей) та ін.

Також науковцями досліджується психологічна підготовка фахівців, зокрема: непедагогічних університетів (Д. Дзвінчук, В. Козаков); учителів початкового навчання (С. Лисенко); майбутніх учителів в умовах навчально-наукового комплексу «коледж-університет» (Н. Денисова); учителя початкових класів до роботи із соціально занедбаними учнями (В. Вовк); майбутнього вчителя фізики (С. Ткаченко); інспекторів прикордонної служби (О. Самохвалов); працівників підрозділів швидкого реагування міліції України (О. Корнєв); обслуговуючого персоналу морського транспорту (С. Ситнік); льотного складу до діяльності в умовах тривалих перерв між польотами (І. Окуленко); майбутніх юристів до професійної діяльності (Ю. Бойко); учнів спеціалізованих загальноосвітніх закладів міліції до навчально-службової діяльності в системі МВС України (І. Машук). Психологічна освіта старшокласників як чинник їх життєвого самовизначення досліджувалася С. Панченко; шляхи підвищення ефективності вивчення психології у ВНЗ - В. Семиченко; психологічний зміст інноваційної освіти в контексті культурно-психологічного простору - О. Гуменюк.

Проте специфіка професійної діяльності фахівців агрономічного профілю та психологічний складник у ній у зазначених дослідженнях не розглядалися. 
Mema cmammi- виявити специфіку професійної діяльності фахівців агрономічного профілю та виокремити в ній психологічний складник.

Агропромисловий комплекс - це сукупність галузей, що здійснюють виробництво, переробку i збереження, доведення до споживача продукції, виготовленої із сільськогосподарської сировини [4]. Сільськогосподарська продукція виробляється за допомогою живих організмів (рослин, тварин, мікроорганізмів), які часто функціонують як засоби виробництва. Оскільки ці живі організми розвиваються за біологічними законами, цим і зумовлюється залежність процесу виробництва від природних чинників. До процесу сільськогосподарського виробництва залучено такі ресурси: основні й оборотні фонди, жива праця і земля. Однією $з$ причин цього $є$ те, що в сільському господарстві виробничий процес перебуває в тісному взаємозв'язку з природними процесами. Отже, аграрники працюють в умовах ризику і невизначеності.

У сільському господарстві робочий період не збігається 3 періодом виробництва (одержання готової продукції). У результаті цього виникає сезонність виробництва продукції, що зумовлює виконання значного обсягу робіт у стислий термін і в нерівномірному використанні робочої сили та засобів виробництва. Порівняно 3 іншими галузями в сільському господарстві значно ускладнюється процес управління виробництвом. Це зумовлено: необхідністю розвивати в аграрних підприємствах кілька галузей, які істотно відрізняються технологією й організацією виробництва; розосередженістю працівників по великій території, а відтак складністю прийняття оперативних рішень внаслідок зміни виробничої ситуації; необхідністю докладання зусиль задля організації збереження власного й орендованого майна, вирощеного врожаю; потребою залучення сезонної робочої сили в періоди сільськогосподарських робіт і труднощами управління нею; ненормованим графіком роботи працівників аграрних підприємств унаслідок необхідності своєчасного виконання важливих технологічних операцій у стислі (оптимальні) строки [1, с. 6-12].

Відповідно до мети дослідження проаналізуємо сутність професійної діяльності агрономічного профілю. Агрономія в сучасному розумінні об'єднує сукупність наук про вирощування рослин за якомога менших енергетичних затрат та одночасного підвищення їх продуктивності та якості врожаю, про грунти та заходи підвищення їх родючості, раціональне використання сільськогосподарських угідь [2, с. 46].

Агрономічну професію представляють кілька спеціальностей, зокрема, це агрономія, агрохімія і грунтознавство, плодоовочівництво і виноградарство, захист рослин, селекція та насінництво. У господарствах, які спеціалізуються на вирощуванні зернових, овочевих та інших культурних рослин, провідна роль відводиться агрономам. Виокремлюють такі агрономічні посади: головний агроном (або старший агроном), агроном із насінництва, агроном-овочівник, агрономагрохімік, агроном із захисту рослин, агрономи відділення. Агроном відділення здійснює планування, технологічне й організаційне керівництво виконанням заходів щодо вирощування сільськогосподарських культур, збирання врожаю, раціонального використання сільськогосподарських угідь, техніки, робочої сили, агрохімікатів та інших матеріальних ресурсів у землеробстві. Переважно у господарствах провідним $\epsilon$ відділ рослинництва, на якому зосереджено виробництво зерна, овочів, плодів тощо. За відділом закріплюють земельні угіддя, 
техніку, основні й оборотні засоби, необхідну кількість робітників (бригади, ланки, цехи) [2, с. 251].

У деяких господарствах уведено такі посади, як: агроном із садівництва, овочівництва, кормовиробництва тощо. До їх обов'язків входить технологічне й організаційно-економічне керівництво в садівництві, овочівництві, кормовиробництві.

До професійних обов'язків агронома входить піклування про вдосконалення виробничої агрономічної культури, а саме: дотримання сівозмін, раціональна система механічного оброблення грунту, своєчасне внесення органічних i мінеральних добрив, проведення меліоративних робіт, систематична боротьба 3 ерозією грунтового покриву, а також з бур'янами, шкідниками і хворобами рослин, дотримання сортової технології вирощування сільськогосподарських культур, полезахисне лісорозведення та інші заходи, що підвищують культуру землеробства. Агроном планує проведення сільськогосподарських робіт з урахуванням великої кількості чинників, зокрема особливостей агрономічної культури, погодних умов, стану грунту тощо. Він спостерігає за ростом і розвитком рослин, планує підкормку, полив, прополювання та інші заходи, які дозволяють домогтися максимально високого врожаю; відповідає за захист рослин від шкідників і хвороб, за необхідності здійснює лікування рослин; обирає сорти, що найбільше підходять для вирощування в конкретних умовах, виконує селекційну роботу [2, с. 253 ; 3, с. 2324].

Варто зазначити, що фахівці агрономічного спрямування можуть працювати не тільки в сільських господарствах, а й у контрольно-насіннєвих лабораторіях, карантинних інспекціях i елеваторно-складських господарствах, на селекційних станціях і сортодільницях, менеджерами 3 продажу продукції рослинництва, захисту рослин, мінеральних добрив тощо, у навчальних закладах, агрохімічних лабораторіях, сільськогосподарських виробничих управліннях, проектних установах, де беруть участь в агрохімічних і грунтових обстеженнях, проведенні бонітування грунтів, у розробці проектів меліорації низькородючих грунтів і систем удобрення культурних рослин. Сучасна аграрна освіта надає змогу здобути фах дослідника 3 агрономії, агронома-технолога, агроінженера, фахівців, які спеціалізуються на агрономічному менеджменті, буряківництві, кормовиробництві, насінництві, садово-парковому господарстві тощо [2, с. 252].

Зважаючи на специфіку професійної діяльності, агрономові необхідно мати добре розвинені екстероцептивні (зорові, слухові, нюхові, дотикові) відчуття і сприймання; кмітливість, гнучкість, самостійність мислення, практичне наочнообразне мислення; бути здатним до аналізу причин явищ, розв'язання розумових задач із діагностування i прогнозування, передбачення віддалених наслідків власних дій; мати високий рівень розвитку концентрації і розподілу уваги, спостережливості; високий рівень розвитку довготривалої образної (зорової, слухової, нюхової, дотикової) пам'яті; бути здатним швидко приймати нестандартні рішення в екстремальних ситуаціях; працювати в умовах ненормованого графіка і в різних погодних умовах; творчо ставитися до праці; бути емоційно стійким; відповідальним за життя та здоров'я рослин і людей; організованим, наполегливим, ініціативним, терплячим; мати високий рівень самовладання; організаторські і комунікативні здібності. Оскільки агроном працює в колективі, йому необхідно вибудовувати стосунки 3 людьми 3 урахуванням їхніх вікових особливостей, 
інтересів, особливостей темпераменту і характеру, вміти ставити цілі і мотивувати підлеглих до виконання професійних обов'язків.

У результаті здійсненого аналізу професійних обов'язків, виробничих функцій, типових задач професійної діяльності фахівців агрономічного профілю, потенціалу фаху щодо працевлаштування і застосування на практиці набутих професійних знань, умінь і навичок, було виявлено специфіку їхньої професійної діяльності та виокремлено в ній психологічний складник.

\section{Література}

1. Андрійчук В. Г. Економіка аграрних підприємств : [підручник] В. Г. Андрійчук. - К. : КНЕУ, 2002. - 624 с. 2. Введення до спеціальності : [навч. посіб.] / за ред. І. Д. Примака, О. І. Примак. - К. : Центр учбової літератури, 2009. 392 с. 3. Грецов А. 100 популярных профессий. Психология успешной карьеры для старшеклассников и студентов / А. Грецов, Т. Бедарева. - СПб. : Питер, 2008. 272 с. 4. Економічна теорія: [посібник] / за заг. ред. Є. М. Воробйова. - ХарківКиїв : Корвін, 2003. - 704 с.

\section{Олександра Потапова}

\section{ДО ПРОБЛЕМИ ФОРМУВАННЯ КРИТИЧНОГО МИСЛЕННЯ У СТУДЕНТІВ ТЕХНІЧНИХ ВНЗ ПІД ЧАС ВИВЧЕННЯ МАТЕМАТИЧНИХ ДИСЦИПЛІН}

Потапова О. М. До проблеми формування критичного мислення у студентів технічних ВНЗ під час вивчення математичних дисциплін.

У статті досліджується проблема розвитку критичного мислення студентів вищих навчальних закладів в науковій i методичній літературі. На основі зіставлення, порівняння, узагальнення наукової інформації уточнюється сутність поняття «критичне мислення» та доводиться необхідність його формування у студентів ВНЗ як складника майбутньої фахової компетентності.

Ключові слова: математичні дисципліни, критичне мислення, технічний вищий навчальний заклад, професійна компетентність.

Потапова О.Н. К К проблеме формирования критического мышления у студентов технических вузов при изучении математических дисциплин.

В статье исследуется проблема развития критического мышления студентов высших учебных заведений в научной и методической литературе. На основе сопоставления, сравнения, обобщения научной информации уточняется сущность понятия «критическое мышление» и обосновывается необходимость его формирования у студентов высших учебных заведений как составляющей будущей профессиональной компетентности.

Ключевые слова: математические дисциплины, критическое мышление, техническое высшее учебное заведение, профессиональная компетентность.

Potapova A. N. On the problem in formation of critical thinking by the students of technical higher education institution in the studying of mathematical disciplines.

The problem of developing critical thinking by students of technical higher education institution is researched in this article, with the help of scientific and technical literature. The essence of the concept of «critical thinking» is determined on the basis of formation, composition and generalization of scientific information and is proved the 